\title{
AN EMPIRICAL STUDY ON POST DIVORCE ENFORCEMENT OF COURT ORDERS IN MALAYSIA
}

\author{
Muhamad Helmi Md Said* \\ Najibah Mohd Zin** \\ Nora Abdul Hak*** \\ Noraini Md Hashim****
}

\begin{abstract}
This study investigates problems on the enforcement of court orders issued by the civil courts in divorce cases in Malaysia. Although the civil courts are guided by comprehensive statutory laws, however, issues on matters related to the enforcement of court orders especially maintenance orders are still unresolved. Therefore, this study is undertaken to examine and identify problems that have caused the failure to enforce these orders, post-divorce. A survey was conducted on one hundred and sixty-seven respondents came from five regions in Malaysia. The survey using questionnaires was the main method of collecting data. To support the empirical evidence, semi-structured interviews were also conducted in this study. The study discloses an obvious co-relation between complex and lengthy processes, unnecessary time consuming and costs inefficiency with the enforcement of orders after the divorce has taken place. This article is a prelude to a projected study on the enforcement of court orders issued by Civil Courts whereby the result will be useful for further improvement of the existing legal provisions in Malaysia.
\end{abstract}

Keywords: enforcement of court orders, procedure for enforcement, post-divorce issues, effect of non-Muslim divorce.

* Law lecturer at Faculty of Laws, National University of Malaysia, Email: mhelmisaid@ukm.edu.my.

** $\quad$ Professor at Ahmad Ibrahim Kulliyyah of Laws, International Islamic University Malaysia. Email: najibah@iium.edu.my.

*** Professor at Ahmad Ibrahim Kulliyyah of Laws, International Islamic University Malaysia. Email: ahnora@iium.edu.my.

**** Associate Professor at Ahmad Ibrahim Kulliyyah of Laws, International Islamic University Malaysia. Email: norainim@iium.edu.my. 


\title{
KAJIAN EMPIRIKAL MENGENAI MASALAH PENGUATKUASAAN PERINTAH MAHKAMAH PASCA PERCERAIAN DI MALAYSIA
}

\begin{abstract}
ABSTRAK
Kajian ini bertujuan untuk menyelidiki masalah penguatkuasaan perintah mahkamah yang dikeluarkan oleh mahkamah sivil bagi kes cerai di Malaysia. Walaupun mahkamah sivil berpandukan undangundang yang komprehensif, namun begitu, isu-isu mengenai perkara yang berkaitan dengan perintah penguatkuasaan terutamanya nafkah masih belum dapat diselesaikan. Oleh yang demikian, kajian ini dijalankan untuk mengkaji dan mengenal pasti masalah-masalah yang menyebabkan kegagalan untuk menguatkuasakan perintah mahkamah yang berkaitan dengan isu-isu pasca perceraian. Sampel kajian terdiri daripada seratus enam puluh tujuh responden yang diambil dari lima wilayah di Malaysia. Tinjauan ini menggunakan borang soal selidik dan ia merupakan kaedah utama dalam mengumpul data. Bagi menyokong data empirikal dari kajian ini, wawancara semi-berstruktur juga telah dijalankan dalam kajian ini. Kajian ini mendedahkan terdapat hubungan yang jelas antara proses yang kompleks dan panjang, penggunaan masa yang tidak begitu efisien dan ketidakcekapan kos dengan perintah penguatkuasaan isu pasca perceraian. Artikel ini merupakan permulaan kepada kajian yang dijalankan mengenai penguatkuasaan perintah di mahkamah sivil dimana hasilnya berguna untuk memperbaiki undangundang yang sedia ada di Malaysia.
\end{abstract}

Kata kunci: penguatkuasaan perintah mahkamah, tatacara untuk penguatkuasaan, isu pasca perceraian, kesan dari perceraian bukan Islam.

\section{INTRODUCTION}

Malaysia has fairly comprehensive legislations and procedures relating to the order of maintenance and its enforcement as stipulated in the Law Reform (Marriage and Divorced) Act 1976 (LRA 1976), Rules of Court 2012, Married Women and Children (Maintenance) Act 1950 and Married Women and Children (Enforcement of Maintenance) Act 1968 (Revised 1988). Nevertheless, there is a significant weakness in the enforcement of maintenance orders especially if the former husband or father who is responsible for payment of the maintenance fails to cooperate or negligently defaulted. This problem does not only 
affect the Muslim families, but also the non-Muslim families in Malaysia. Complaints against enforcement of the orders have created feelings of discontentment among single mothers which had led to the creation of the maintenance enforcement unit known as the "Bahagian Sokongan Keluarga" (BSK) within the Department of Syariah Judiciary Malaysia (JKSM). The establishment of BSK was the result of the decision of the Islamic National Council meeting chaired by the $5^{\text {th }}$ Rt. Honourable Prime Minister of Malaysia, in 2008. However, this ruling only involves the order issued by the Syariah Courts. Although the non-Muslims are essentially facing the same problems, ${ }^{1}$ no such unit has been established under the Civil Courts.

In general, the discussion will emphasise the need for enforcement units to be set up in the civil courts to ensure that all maintenance related court orders can be enforced more effectively. This situation will be able to provide confidence to the public on the importance of courts as an institution for them to claim their rights. This is due to the fact that there are some non-Muslim mothers who refused to apply for maintenance in the court. They would rather work hard to support their families rather than resort to legal aid. This is perhaps due to their ignorance of their rights, financial constraints and community stigma on the widow status as well as complicated court procedures. Therefore, an action towards the improvement of the existing system needs to be taken to ensure the survival of these vulnerable groups to be more secured.

\section{RESEARCH METHODOLOGY}

Quantitative and qualitative designs are the backbone of this feasibility study allowing for a comprehensive and holistic approach whereby field-based findings from stakeholders are crucial in proposing a sustainable and viable enforcement mechanism model acceptable to those who are directly involved in its future implementation.

The population of this study included divorced non-Muslim couples totalling 38,620 persons all over Malaysia who were recorded up to 2015. Although the initial target for the survey was 400 respondents, due to time and financial constraints, as well as

This issue has been raised during the National Family Policy's workshop 2012 organised by the LPPKN and Ahmad Ibrahim Kulliyyah of Laws 
difficulties in obtaining cooperation from the divorced mothers, the questionnaire was eventually answered by 167 divorced non-Muslim respondents. Perhaps, with the results of this study, a follow-up study may also be implemented throughout Malaysia to include the indigenous people of Peninsular Malaysia. Due to time constraint, in the present study, sampling by chance (convenience) was adopted. This is a kind of non-probability sampling method where samples are taken from a group of people who are easy to be contacted or reached. ${ }^{2}$ There is no other criteria for sampling method unless the people are available and ready to participate. ${ }^{3}$ In addition, this type of sampling method does not require random sampling to be generated, since the only criteria is whether the participants agreed to participate or not. The sample is easily selected because the sample members are easily accessible and this sample was selected based on their readiness and voluntariness. One of the reasons for its selection is the many advantages that it provides. This method is very quick, easy to find and cost effective, making it an attractive choice for researchers. ${ }^{4}$ However, the lack of sampling obtained under this method will result in the likelihood of bias and the results from the sample may not be generalised to larger target populations. Therefore, the conclusions based on simple sampling are made solely on the sample itself. ${ }^{5}$

A survey was conducted in selected states in Malaysia representing five regions namely the Northern region, Central region, East Coast, South region and East Malaysia inclusive of Sabah and Sarawak. Questionnaires was administered and distributed to collect the data from respondents. Semi structured interviews were also conducted with the respondents who have the experience of being directly involved in divorce. The interview was conducted at Bandar Sunway and the names of the interviewee cannot be disclosed in the writing due to anonymity and confidentiality issue. The collected data was analysed using SPSS version 22.

2 Saunders, M; Lewis, P; Thornhill, A (2012). Research Methods for Business Students (6th ed.).

3 Ibid.

4 Henry, Gary T. (1990). Practical sampling (ed.). Newbury Park: Sage Publications, pages.117.

5 Bornstein, Marc H.; Jager, Justin; Putnick, Diane L. (28 April 2017). "Sampling in Developmental Science: Situations, Shortcomings, Solutions, and Standards". Developmental Review. 33(4): pages.359. 


\section{RESEARCH OBJECTIVE}

This article analyses post-divorce enforcement of court orders from civil courts in Malaysia with the view of accentuating existing problems. This will allow improvements to be made to the existing law so as to allow better access to justice for everyone, especially single mothers.

\section{LITERATURE REVIEW}

Prior studies have shown that there are various problems arising after divorce where the issue of maintenance claims by the ex-wives and minors as well as its enforcement is a major issue that has always been a grievance in the society that affects the quality of their lives postdivorce. The situation is burdened with financial problems, especially for women who have no income to cater to their daily needs. This burden will worsen if the divorced women also bear the responsibility of caring for their children. This is coupled with other problems such as custody of the child and the division of the matrimonial properties.

There are several studies that have been completed in regard to the problems encountered after the divorce, in particular those related to the claims for maintenance, custody and claims of properties. These problems have admittedly been around for a very long time and continues to plague the parties even after the divorce proceeding has ended. Sridevi Thambapillay in her thesis entitled A Critical Analysis of the Statutory Framework of Maintenance of Non-Muslim Children and Young Persons in Malaysia focuses on the rights of children in a comprehensive way. This thesis in the form of qualitative and quantitative research has analysed the interested perceptions in relation to the law relating to the maintenance of children and the problems connected to its enforcement. The thesis has also made comparisons on the maintenance laws in force in Malaysia and other countries such as England, Singapore and Australia at the same time providing recommendations for the improvement of the existing legislation. ${ }^{6}$ In her thesis, she has emphasized on the importance of reminding the authorities concerned about the need to review the existing laws and to

6 Sridevi Thambapillay A Critical Analysis of the Statutory Framework of Maintenance of Non-Muslim Children and Young Persons in Malaysia. (Kuala Lumpur: Universiti Malaya, 2017), v-vi. 
overcome the weaknesses that is apparent especially in restoring the legal rights of the neglected children. ${ }^{7}$ In the previous year, in 2016, Zuliza Mohd. Kusrin and Nurhidayah Muhammad Hashim have written an article in Kanun journal entitled Pemelukan Islam Pasangan Perkahwinan Sivil: Isu Berbangkit dan Cadangan Penambahbaikan Menurut Undang-Undang Malaysia (Conversion to Islam by civilly married couples: Arises Issues and Proposal for Improvement according to the Laws of Malaysia). This article highlights the legal conflicts that exists within current family laws primarily those under the civil system. Mention shall also be made on the Syariah laws in Malaysia but it will be limited to the issues that arises consequent to the conversion to Islam and where the non-converting party claims for maintenance. ${ }^{8}$ The authors have also submitted several proposals in accordance with the provisions of the existing laws based on the opinions of some legal analysts. At the conclusion of the article, the authors have suggested, among others, to amend section 51 of the LRA 1976 to provide equal rights among spouses who were married through the civil law and for the Council of Rulers to establish a Judicial Committee comprising those who have qualification both in civil and Syariah as a special forum to hear and try family matters involving parties of different religion. ${ }^{9}$

Heama Latha Nair, Saroja Dhanapal and Jenita Kanapathy in their article entitled, A Review of Married Women and Children (Maintenance) Act 1950 and Married Women and Children (Enforcement of Maintenance) Act $1968^{10}$ provided feedbacks from the Malaysian Law Reform Committee from the Department of Legal Affairs (Bahagian Hal Ehwal Undang-Undang (BHEUU). Namely, they identified the need for the ministry to be accountable for the enforcement of the laws relating to maintenance so as to provide

7 Ibid.

8 Zuliza Mohd. Kusrin and Nurhidayah Muhammad Hashim, Pemelukan Islam Pasangan Perkahwinan Sivil: Isu Berbangkit dan Cadangan Penambahbaikan Menurut Undang-Undang Malaysia in Kanun. (January 2016), pages 28 .

9 Ibid. pages 38-40.

10 Nair, H., Dhanapal, S. \& Kanapathy, J., A Review of Married Women and Children (Maintenance) Act 1950 and Married Women and Children (Enforcement of Maintenance) Act 1968, European Journal of Business and Social Sciences, 3 No.4 (July 2014.): 257-272. 
consistent protection against women and children throughout Malaysia.

In 2013, Leong Wai Kum published a family law textbook in Singapore entitled Elements of Family Law in Singapore. ${ }^{11}$ Although the author concentrates on the legal position in Singapore, the part in relation to maintenance is relevant particularly because he did not limit the discussion on maintenance of spouses and children only, but also emphasizes the responsibility of the children to bear their elderly parents. ${ }^{12}$ More importantly, Chapter 12 focuses on one dedicated subtopic to explain the enforcement of maintenance order. ${ }^{13}$ Procedural laws relating to the enforcement of women and children's maintenance orders are similar to the provisions under the Women's Charter. Among the forms of enforcement orders include orders for detention of wages, fines, financial counselling, community service orders, reports to credit bureaus, declaration notice to re-marry and others. ${ }^{14}$ In this book too, the author touches on the development of the nonMuslim family law as well as the Islamic law and its administration in Singapore. Some of the mechanisms of enforcement orders could be emulated in the Malaysian context. ${ }^{15}$

Yip Yook Khai's book, ${ }^{16}$ entitled, Prosiding Perceraian dan Hal Ehwal Perkahwinan: Prosedur dan Borang-Borang (Divorce and Marriage matters: Procedures and its forms)" was published in 2012 is also relevant for review. The publication of this textbook is a material reference on the detailed and technical provisions as well as procedures that operate under the Law Reform (Marriage and Divorce) Act 1976 and the Divorce and Marriage Procedure Rules 1980. This book serves as a guide and general reference to assist the lawyers in the preparation of relevant documents relating to the marriage affairs proceedings before the High Court of Malaya, and also Sabah and Sarawak, including matters related to maintenance.

11 Leong Wai Kum Elements of Family Law in Singapore. Edisi Kedua. ( Singapura: LexisNexis, 2013).

12 Leong Wai Kum Elements of Family Law in Singapore. See Chapters 12, 13 and 18.

13 Ibid. p. 435.

14 Ibid. page 435-442.

15 Ibid.

16 Certified Interpreter (Tionghua) who has been in service with the Malaysian Judiciary for 42 years. 
Meanwhile, Shamsuddin Suhor described in breadth the concept of maintenance in his legal textbook, Guide to the Law Reform (Marriage and Divorce) Act 1976 (Act 164). ${ }^{17}$ A discussion and study on the maintenance for non-Muslims was broken into 2 divisions: (i) maintenance of spouses, and (ii) maintenance of the child or children. ${ }^{18}$ The maintenance of these children includes legitimate and illegitimate children, adopted children, or a child who has not yet attained the age of 18 years old from the civil marriage. This book too is the main general reference on the non-Muslim family.

In the interim, the study on the enforcement of maintenance orders in the Syariah Courts started with the Baseline Study in Syariah Court Gombak Timur in 2015. This study involved document analysis of four court cases that were still active pending disposal. Among the items reviewed in the files were the duration taken from the commencement of the case in court up to the date the maintenance order was duly executed together with the costs that the wife had to endure. The results show that there is serious delay in enforcing the maintenance order due to long and complicated court procedures. This opened up an opportunity for the party liable to pay the maintenance to wilfully avoid and default his duties as ordered by the court. Although in most cases, the maintenance order is obtain through the sulh process, there are still husbands who deliberately and negligently fail to pay the maintenance of their children. Eventually, these situations had hindered the mothers and divorced women from continuing to proceed with the enforcement and execution of the maintenance orders in court. ${ }^{19}$

From the literature reviewed, it was obvious that there was a need to address the issue plaguing many divorced women when claiming maintenance from their ex-husbands. Hence, this article seeks to fill this gap by investigating the loopholes in the existing laws as well as to also gage the perspectives of the affected women that is the

17 Shamsuddin Suhor, Panduan Akta Membaharui Undang-Undang Perkahwinan dan Perceraian 1976 (Akta 164). Second Edition. (Kuala Lumpur: Dewan Bahasa dan Pustaka, 2011), p. 227.

18 Ibid.

19 Mohd Zin, N., Md Hashim, N., Hak, N.A., Che Soh, R., Ibrahim, K. dan Md Said, M.H., A Baseline Study of the Enforcement of Nafkah Orders in the Selangor Syariah Court, Pertanika, J. Soc. Sci. \& Hum. (s): 329338 (2015). 
women who had experienced difficulties in enforcing the maintenance orders issued by the Courts.

\section{THE DATA OBTAINED}

500 questionnaires were distributed to the parties involved at an early stage. A total of 265 questionnaires have been returned within the prescribed time frame. However, only 167 out of 265 questionaires could be counted in the data analysis, while the excess of the 98 questionnaires were void.

\section{Demographic Information and Respondents' Background}

\section{Age Group of Respondents}

Table 2.1 shows the age group of respondents. Respondents with the age group of 36 to 45 years made up the highest percentage of the respondents which came up to 43.7 per cent. This is followed by the age group of 46 to 55 years ( 26.3 percent). The lowest age group is 25 years and below that only came up to 3.0 per cent from the total respondents.

Table 2.1: Age Group of Respondent

\begin{tabular}{|c|c|c|c|}
\hline \multirow{4}{*}{ Age (Years) } & Category & Frequency & Percentage \\
\cline { 2 - 4 } & $36-45$ & 73 & 43.7 \\
\cline { 2 - 4 } & $46-55$ & 44 & 26.3 \\
\cline { 2 - 4 } & $26-35$ & 34 & 20.4 \\
\cline { 2 - 4 } & 56 and above & 11 & 6.6 \\
\cline { 2 - 4 } & 25 and below & 5 & 3.0 \\
\cline { 2 - 4 } & Total & $\mathbf{1 6 7}$ & $\mathbf{1 0 0 . 0}$ \\
\hline
\end{tabular}

\section{Race}

Table 2.2 shows the races of the respondents involved in the study. Respondents with Indian heritage recorded the highest percentage of the respondents making it 29.9 per cent. This is followed by Chinese 
respondents which made up 28.7 per cent. The natives of Sabah (21.0 per cent) and natives of Sarawak (18.0 per cent). The Punjabi recorded the lowest percentage of 2.4 per cent.

Table 2.2: Race

\begin{tabular}{|c|c|c|c|}
\hline \multirow{4}{*}{ Race } & Category & Frequency & Percentage \\
\cline { 2 - 4 } & Indian & 50 & 29.9 \\
\cline { 2 - 4 } & Chinese & 48 & 28.7 \\
\cline { 2 - 4 } & Native of Sabah & 35 & 21.0 \\
\cline { 2 - 4 } & Native of Sarawak & 30 & 18.0 \\
\cline { 2 - 4 } & Punjabi & 4 & 2.4 \\
\cline { 2 - 4 } & Total & $\mathbf{1 6 7}$ & $\mathbf{1 0 0 . 0}$ \\
\hline
\end{tabular}

\section{Type of Residence}

In this study, the percentage of urban residents (63.5\%) involved exceeds the percentage of respondents living in the village $(36.5 \%)$ as shown in table 2.3 .

Table 2.3: Type of Residence

\begin{tabular}{|c|c|c|c|}
\hline \multirow{4}{*}{ Type of Residence } & Category & Frequency & Percentage \\
\cline { 2 - 4 } & Urban & 106 & 63.5 \\
\cline { 2 - 4 } & Village & 61 & 36.5 \\
\cline { 2 - 4 } & Total & $\mathbf{1 6 7}$ & $\mathbf{1 0 0 . 0 0}$ \\
\hline
\end{tabular}

\section{Number of Children under the Age of 18 Years Old}

Almost majority of the respondents (79.6 per cent) in this study have children under the age of 18 years and only 20.4 per cent of the respondents did not have children under 18 years as shown in table 2.4. 
Table 2.4: Children under the age of 18 years old

\begin{tabular}{|c|c|c|c|}
\hline \multirow{4}{*}{$\begin{array}{c}\text { Children under the } \\
\text { age of } 18\end{array}$} & Category & Frequency & Percentage \\
\hline & Yes & 133 & 79.6 \\
\hline & No & 34 & 20.4 \\
\hline & Total & 167 & 100.0 \\
\hline
\end{tabular}

\section{Number of Children above the Age of 18 Years Old}

Nearly three-quarters of the respondents (69.5 per cent) in this study do not have children above the age of 18 years and only 30.5 per cent of the respondents have children above 18 years as shown in table 2.5.

Table 2.5: Children above the age of 18 years old

\begin{tabular}{|c|c|c|c|}
\hline \multirow{4}{*}{$\begin{array}{c}\text { Children above the } \\
\text { age of } 18\end{array}$} & Category & Frequency & Percentage \\
\hline & No & 116 & 69.5 \\
\hline & Yes & 51 & 30.5 \\
\hline & Total & 167 & 100.0 \\
\hline
\end{tabular}

\section{Level of Education}

Table 2.6 shows the level of the respondents' education involved in this study. The level of education in high school recorded the highest percentage with 61.1 per cent, followed by respondents with diploma, matriculation and college (17.4 per cent). Respondents' education level at undergraduate/degree, master's and doctoral degrees recorded the lowest percentage of 4.2 per cent.

Table 2.6: Level of Education

\begin{tabular}{|l|l|c|c|}
\hline \multirow{4}{*}{$\begin{array}{c}\text { Level of } \\
\text { Education }\end{array}$} & \multicolumn{1}{|c|}{ Category } & Frequency & Percentage \\
\cline { 2 - 4 } & High School & 102 & 61.1 \\
\cline { 2 - 4 } & Diploma/Matric/College & 29 & 17.4 \\
\cline { 2 - 4 } & Primary School & 15 & 9.0 \\
\cline { 2 - 4 } & No formal Education & 7 & 4.2 \\
\cline { 2 - 4 } & Degree/Undergraduate & 7 & 4.2 \\
\hline
\end{tabular}




\begin{tabular}{|c|c|c|c|}
\hline \multirow{2}{*}{ Total } & Master/PHD & 7 & 4.2 \\
\cline { 2 - 4 } & $\mathbf{1 6 7}$ & $\mathbf{1 0 0 . 0}$ \\
\hline
\end{tabular}

\section{Information of Occupation}

In this study, the percentage of working respondents is (63.5 per cent) over the percentage of non-working respondents (24.0 per cent) as shown in Table 2.7 .

Table 2.7: Working or Non-Working

\begin{tabular}{|c|lc|c|c|}
\hline \multirow{4}{*}{$\begin{array}{c}\text { Working or } \\
\text { Non-Working }\end{array}$} & \multicolumn{2}{|c|}{ Category } & Frequency & Percentage \\
\cline { 2 - 5 } & Yes & 127 & 76.0 \\
\cline { 2 - 5 } & No & 40 & 24.0 \\
\cline { 2 - 5 } & \multicolumn{2}{|c|}{ Total } & $\mathbf{1 6 7}$ & $\mathbf{1 0 0 . 0}$ \\
\hline
\end{tabular}

\section{General Information about Divorce}

\section{Divorce Method}

There are two ways of divorce i.e., by mutual consent and contested. Table 2.8 shows that over half of respondents chose to divorce through contested method (50.3 per cent) as compared to mutual consent (48.5 per cent).

Table 2.8: Divorce Method

\begin{tabular}{|c|c|c|}
\hline Divorce Method & Frequency & Percentage \\
\hline Irrelevant & 2 & 1.2 \\
\hline Mutual Consent & 81 & 48.5 \\
\hline Contested & 84 & 50.3 \\
\hline Total & 167 & 100.0 \\
\hline
\end{tabular}

\section{Problems Faced by Divorcee}

This question allows respondents to select more than one answer. Table

2.9 below shows that the main problems faced by divorced women is 
related to maintenance ( 81.4 per cent) followed by child custody ( 43.7 per cent) and matrimonial property (40.1 per cent).

Table 2.9: Problems

\begin{tabular}{|c|c|c|c|}
\hline Problems & & Frequency & Percentage \\
\hline \multirow{2}{*}{ Custody } & Yes & 94 & 43.7 \\
\hline & No & 73 & 56.3 \\
\hline Total & & 167 & 100.0 \\
\hline \multirow{2}{*}{ Matrimonial Property } & Yes & 67 & 40.1 \\
\hline & No & 100 & 59.9 \\
\hline Total & & 167 & 100.0 \\
\hline \multirow{2}{*}{ Maintenance } & Yes & 136 & 81.4 \\
\hline & No & 31 & 18.6 \\
\hline Total & & 167 & 100.0 \\
\hline
\end{tabular}

\section{Level of Agreement on General Problem of Divorce}

Table 2.10 shows the level of agreement on the general problem of divorce. More than half of the respondents agree with all the common problems of divorce. The respondents in this study agreed that the main issues arising after being granted with the court order are "child custody" (67.4 per cent) and "matrimonial property" (65.3 per cent). More than half of respondents agreed that it is "difficult to enforce divorce order" (64.9 per cent). The respondents also agreed that "the main issue arising after being granted with the court order is the maintenance of the wife" (64.3 per cent).

Despite the above, the respondents agreed that they are "very satisfied with the enforcement of divorce order" (62.5 per cent). The sixth general problem agreed by the respondent is, "the main issue arising after the court order being granted is the maintenance of the child" (61.8 per cent). They also agreed that, "even after obtaining absolute decree, there are still issues that have not been resolved" (60.8 per cent). The last known common problem is, "the court provide assistance in enforcing the divorce order" (50.7 per cent). Overall, the 
satisfaction of the respondents' level of the agreement on general problem of divorce is 62.2 per cent.

Table 2.10: Level of Agreement on General Problem of Divorce

\begin{tabular}{|c|c|c|c|c|c|c|c|c|c|}
\hline \multirow{2}{*}{$\begin{array}{c}\text { No } \\
\text { • }\end{array}$} & \multirow{2}{*}{$\begin{array}{l}\text { General } \\
\text { Divorce } \\
\text { Problems }\end{array}$} & \multicolumn{5}{|c|}{ Level of Agreement (\%) } & \multirow{2}{*}{ Min } & \multirow{2}{*}{ SD } & \multirow{2}{*}{$\%$} \\
\hline & & 1 & 2 & 3 & 4 & 5 & & & \\
\hline 1 & $\begin{array}{l}\text { The main } \\
\text { issue } \\
\text { arising after } \\
\text { being } \\
\text { granted } \\
\text { with the } \\
\text { court order } \\
\text { is child } \\
\text { custody. }\end{array}$ & 9.6 & 7.2 & $\begin{array}{c}40 . \\
7\end{array}$ & $\begin{array}{c}21 . \\
6\end{array}$ & $\begin{array}{c}21 . \\
0\end{array}$ & $\begin{array}{c}3.37 \\
1\end{array}$ & $\begin{array}{c}1.74 \\
5\end{array}$ & $\begin{array}{c}67 . \\
4\end{array}$ \\
\hline 2 & $\begin{array}{l}\text { The main } \\
\text { issue } \\
\text { arising after } \\
\text { being } \\
\text { granted } \\
\text { with the } \\
\text { court order } \\
\text { is } \\
\text { matrimonial } \\
\text { property. }\end{array}$ & 9.6 & 9.0 & $\begin{array}{c}46 . \\
1\end{array}$ & $\begin{array}{c}16 . \\
2\end{array}$ & $\begin{array}{c}19 . \\
2\end{array}$ & $\begin{array}{c}3.26 \\
4\end{array}$ & $\begin{array}{c}1.15 \\
8\end{array}$ & $\begin{array}{c}65 . \\
3\end{array}$ \\
\hline 3 & $\begin{array}{l}\text { It is } \\
\text { difficult for } \\
\text { me to } \\
\text { enforce } \\
\text { divorce } \\
\text { order. }\end{array}$ & $\begin{array}{c}10 . \\
2\end{array}$ & $\begin{array}{c}13 . \\
8\end{array}$ & $\begin{array}{c}41 . \\
9\end{array}$ & 9.6 & $\begin{array}{c}24 . \\
6\end{array}$ & $\begin{array}{c}3.24 \\
6\end{array}$ & $\begin{array}{c}1.25 \\
4\end{array}$ & $\begin{array}{c}64 . \\
9\end{array}$ \\
\hline 4 & $\begin{array}{l}\text { The main } \\
\text { issue } \\
\text { arising after } \\
\text { being } \\
\text { granted } \\
\text { with the } \\
\text { court order } \\
\text { is the } \\
\text { maintenanc }\end{array}$ & $\begin{array}{c}15 . \\
6\end{array}$ & 9.0 & $\begin{array}{c}40 . \\
1\end{array}$ & 9.0 & $\begin{array}{c}26 . \\
3\end{array}$ & $\begin{array}{c}3.21 \\
6\end{array}$ & $\begin{array}{c}1.35 \\
0\end{array}$ & $\begin{array}{c}64 . \\
3\end{array}$ \\
\hline
\end{tabular}




\begin{tabular}{|c|c|c|c|c|c|c|c|c|c|}
\hline & $\begin{array}{l}\text { e of the } \\
\text { wife. }\end{array}$ & & & & & & & & \\
\hline 5 & $\begin{array}{l}\text { I am very } \\
\text { satisfied } \\
\text { with the } \\
\text { enforcemen } \\
\text { t of divorce } \\
\text { order. }\end{array}$ & $\begin{array}{c}19 . \\
8\end{array}$ & $\begin{array}{c}11 . \\
4\end{array}$ & $\begin{array}{c}19 . \\
8\end{array}$ & $\begin{array}{c}34 . \\
7\end{array}$ & $\begin{array}{c}14 . \\
4\end{array}$ & $\begin{array}{c}3.12 \\
6\end{array}$ & $\begin{array}{c}1.35 \\
0\end{array}$ & $\begin{array}{c}62 . \\
5\end{array}$ \\
\hline 6 & $\begin{array}{l}\text { The main } \\
\text { issue } \\
\text { arising after } \\
\text { being } \\
\text { granted } \\
\text { with the } \\
\text { court order } \\
\text { is child } \\
\text { maintenanc } \\
\text { e. }\end{array}$ & $\begin{array}{c}16 . \\
2\end{array}$ & $\begin{array}{c}15 . \\
6\end{array}$ & $\begin{array}{c}36 . \\
5\end{array}$ & 6.6 & $\begin{array}{c}25 . \\
1\end{array}$ & $\begin{array}{c}3.09 \\
0\end{array}$ & $\begin{array}{c}1.37 \\
0\end{array}$ & $\begin{array}{c}61 . \\
8\end{array}$ \\
\hline 7 & $\begin{array}{l}\text { Even after } \\
\text { obtaining } \\
\text { decree } \\
\text { absolute, } \\
\text { there are } \\
\text { still issues } \\
\text { that have } \\
\text { not been } \\
\text { resolved. }\end{array}$ & $\begin{array}{c}16 . \\
2\end{array}$ & $\begin{array}{c}16 . \\
2\end{array}$ & $\begin{array}{c}31 . \\
7\end{array}$ & $\begin{array}{c}19 . \\
2\end{array}$ & $\begin{array}{c}16 . \\
8\end{array}$ & $\begin{array}{c}3.04 \\
2\end{array}$ & $\begin{array}{c}1.29 \\
6\end{array}$ & $\begin{array}{c}60 . \\
8\end{array}$ \\
\hline 8 & $\begin{array}{l}\text { The court } \\
\text { provide } \\
\text { assistance } \\
\text { in enforcing } \\
\text { the divorce } \\
\text { order }\end{array}$ & $\begin{array}{c}31 . \\
1\end{array}$ & $\begin{array}{c}11 . \\
4\end{array}$ & $\begin{array}{c}36 . \\
5\end{array}$ & $\begin{array}{c}15 . \\
0\end{array}$ & 6.0 & $\begin{array}{c}2.53 \\
3\end{array}$ & $\begin{array}{c}1.24 \\
0\end{array}$ & $\begin{array}{c}50 . \\
7\end{array}$ \\
\hline & Total & & & & & & $\begin{array}{c}3.11 \\
1\end{array}$ & $\begin{array}{c}1.34 \\
5\end{array}$ & $\begin{array}{c}62 . \\
2\end{array}$ \\
\hline
\end{tabular}




\section{Level of Satisfaction on Enforcement of Maintenance Order}

More than two-thirds of respondents (69.8 per cent) were satisfied with the proceedings of the Court. Subsequently, the second highest percentage, which is 64.2 per cent indicates that respondents are satisfied with the court order. This suggests that the public is satisfied with the proceedings and the Court's services in obtaining the order for maintenance. However, less than half of the respondents (48.6 per cent) were satisfied with the cooperation of all parties in the implementation of maintenance orders, the execution of maintenance orders ( 45.3 per cent) and duration of execution of maintenance orders (45.6 per cent). This illustrates that the aspect of the maintenance order is at a less satisfactory level than the procurement of the maintenance order. Overall, only 54.7 per cent of the respondents were generally satisfied with the proceedings in the Court and the execution of the maintenance order obtained as in Table 2.11.

Table 2.11: The level of Satisfaction on Maintenance Proceeding in Court

\begin{tabular}{|c|c|c|c|c|c|c|c|c|c|}
\hline \multirow[b]{2}{*}{$\begin{array}{c}\text { No } \\
\text { • }\end{array}$} & \multirow{2}{*}{$\begin{array}{l}\text { The level of } \\
\text { Satisfaction } \\
\text { on } \\
\text { Maintenan } \\
\text { ce } \\
\text { Proceeding } \\
\text { in Court } \\
(\mathrm{N}=167)\end{array}$} & \multicolumn{5}{|c|}{ Level of Satisfaction (\%) } & \multirow[b]{2}{*}{$\begin{array}{c}* \mathbf{M i} \\
\mathbf{n}\end{array}$} & \multirow[b]{2}{*}{ SD } & \multirow[b]{2}{*}{$\%$} \\
\hline & & 1 & 2 & 3 & 4 & 5 & & & \\
\hline 1 & $\begin{array}{l}\text { I am } \\
\text { satisfied } \\
\text { with the } \\
\text { proceeding } \\
\text { of the } \\
\text { Court. }\end{array}$ & 7.8 & 6.0 & $\begin{array}{c}22 . \\
8\end{array}$ & $\begin{array}{c}32 . \\
3\end{array}$ & $\begin{array}{c}26 . \\
3\end{array}$ & $\begin{array}{c}3.49 \\
1\end{array}$ & $\begin{array}{c}1.39 \\
7\end{array}$ & $\begin{array}{c}69 . \\
8\end{array}$ \\
\hline 2 & $\begin{array}{l}\text { I am } \\
\text { satisfied } \\
\text { with the } \\
\text { maintenance } \\
\text { order } \\
\text { granted by } \\
\text { the court. }\end{array}$ & 9.0 & $\begin{array}{c}13 . \\
2\end{array}$ & $\begin{array}{c}27 . \\
5\end{array}$ & $\begin{array}{c}21 . \\
6\end{array}$ & $\begin{array}{c}23 \\
4\end{array}$ & $\begin{array}{c}3.21 \\
0\end{array}$ & $\begin{array}{c}1.44 \\
7\end{array}$ & $\begin{array}{c}64 . \\
2\end{array}$ \\
\hline
\end{tabular}




\begin{tabular}{|c|c|c|c|c|c|c|c|c|c|}
\hline 3 & $\begin{array}{l}\text { I am } \\
\text { satisfied } \\
\text { with the } \\
\text { cooperation } \\
\text { from all } \\
\text { parties in } \\
\text { enforcing } \\
\text { the } \\
\text { maintenance } \\
\text { order. }\end{array}$ & $\begin{array}{c}29 . \\
3\end{array}$ & $\begin{array}{c}12 . \\
0\end{array}$ & $\begin{array}{c}28 . \\
7\end{array}$ & $\begin{array}{c}16 . \\
2\end{array}$ & 7.8 & $\begin{array}{c}2.43 \\
1\end{array}$ & $\begin{array}{c}1.41 \\
2\end{array}$ & $\begin{array}{l}48 . \\
6\end{array}$ \\
\hline 4 & $\begin{array}{l}\text { I am } \\
\text { satisfied } \\
\text { with the } \\
\text { execution of } \\
\text { the } \\
\text { maintenance } \\
\text { order. }\end{array}$ & $\begin{array}{c}29 . \\
9\end{array}$ & $\begin{array}{c}17 . \\
4\end{array}$ & $\begin{array}{c}29 . \\
3\end{array}$ & $\begin{array}{c}10 . \\
2\end{array}$ & 6.6 & $\begin{array}{c}2.26 \\
4\end{array}$ & $\begin{array}{c}1.34 \\
1\end{array}$ & $\begin{array}{c}45 . \\
3\end{array}$ \\
\hline 5 & $\begin{array}{l}\text { I am } \\
\text { satisfied } \\
\text { with the } \\
\text { duration of } \\
\text { time to } \\
\text { execute the } \\
\text { maintenance } \\
\text { order. }\end{array}$ & $\begin{array}{c}31 . \\
1\end{array}$ & $\begin{array}{c}14 . \\
4\end{array}$ & $\begin{array}{c}30 . \\
5\end{array}$ & $\begin{array}{c}10 . \\
2\end{array}$ & 7.2 & $\begin{array}{c}2.28 \\
1\end{array}$ & $\begin{array}{c}1.36 \\
6\end{array}$ & $\begin{array}{c}45 . \\
6\end{array}$ \\
\hline & Total & & & & & & $\begin{array}{c}2.73 \\
5\end{array}$ & $\begin{array}{c}1.39 \\
3\end{array}$ & $\begin{array}{c}54 . \\
7\end{array}$ \\
\hline
\end{tabular}

\section{DISCUSSIONS}

The Laws Relating to Post-Divorce Court Orders and Its Enforcement in the Civil Court.

Married Women and Children (Maintenance) Act 1950 applies only to non-Muslims in West Malaysia, Sarawak and Labuan. It provides for the provision of maintenance to the wives and children during the marriage period. Women in this context include married wives before the enforcement of LRA 1976 and the child referred to under this Act 
includes illegitimate children to obtain maintenance. ${ }^{20}$ The default on the husband's part to comply with the court order related to maintenance will enable the wife to apply to the court to charge a levy on the amount ordered. In addition, the court also has the jurisdiction to allow the wife's application for imprisonment of the husband. ${ }^{21}$ The husband may be exempted from providing maintenance if his wife committed adultery or if she refuses to live with him without reasonable cause. ${ }^{22}$

For the purpose of a maintenance claim, this Act, however, has no specific provision for the period of time in making the claims maintenance. Since the provisions are not available in Malaysia, the courts in Malaysia have referred to the principles in English cases such as in the case of Luscombe v. Luscombe [1962] 1 WLR 313 which states the limit of time in making overdue maintenance claim is one year only. In discussing this matter, there are some cases that can be referred to namely, in the case of Sivajothi K Suppiah V. Kunathasan Chelliah [2000] 3 CLJ 175, Gomez Nee David V. Gomez [1984] 1 LNS 84; Kulasingam V. Rasammah [1980] 1 LNS 225; Amrick Lall V. Sowbaiavati [1973] 1 LNS 3.

It is suggested that the provisions relating to maintenance to be inserted in the LRA for a more cohesive legal framework. The Married Women and Children (Enforcement of Maintenance) Act 1968 provides for the enforcement of maintenance orders applicable to Muslims and non-Muslims in West Malaysia. This Act provides the Court's jurisdiction to issue an attachment of earning order to the husband's employer. The amount payable is in accordance to what the court deems fit, and in the cases where the order fails to be executed due to the failure of the husband and the employer, they may be imprisoned. The term of such imprisonment shall not exceed one year or a fine not exceeding RM1,000.00 or both. ${ }^{23}$ A Muslim applicant must secure a maintenance order from the Syariah Court before an application of enforcement under this Act could be made. ${ }^{24}$

\footnotetext{
20 Section 3(1) of the Married Women and Maintenance Act 1950.

21 Ibid, Section 4.

22 Ibid, Section 5(1) and (2).

23 Section 12 of Married Women and Children (Enforcement of Maintenance) Act 1968.

24 Ibid, Section 14 and 15.
} 
As for its implementation, this Act is applicable to a husband who is employed since the salary deduction may be made through court order on the employer. If the husband is unemployed or self-employed, the court order cannot be enforced through to this Act.

The Law Reform (Marriage and Divorce) Act 1976 ("LRA 1976") is applicable to cases where the wife made an application for maintenance after the court had granted an order for divorce or judicial separation whilst the marriage proceeding is still on going and in cases where the wife is declared dead but later is found to be alive. Pursuant to this Act, the word maintenance was defined as maintenance for exspouse as well as for husbands or ex-husbands subject to certain circumstances such as where the husband is found to be a disabled person. ${ }^{25}$

In relation to child-related laws, the LRA 1976 provides that the father is the first party to be responsible to pay for the child. ${ }^{26}$ The mother may also be ordered to pay maintenance for the child if the court is satisfied that the mother is seen as capable, reasonable and fair to do so. ${ }^{27}$ If the child is normal, the obligation to pay the maintenance continues until the child reaches the age of 18 years. But if the child is experiencing disability or physically and mentally incompetent, the obligation continues until the inability disappears or whichever is later. $^{28}$

However, in 2017, Section 95 of the Act was amended. The purpose of the amendment is to extend the period of maintenance for children who are pursuing further study at an institution of higher learning. The amendment was made following the provisions of the law under the same section which only gives the child a right to maintenance from his father until he reaches the age of 18 years or experiencing physical or mental disabilities. It is difficult for children who are still studying and require expenses to pay for tuition fees and living expenses since a higher learning study begins at the age of 18 . This issue was raised in the case of Ching Seng Woah v Lim Shook Lin ${ }^{29}$ where the Court of Appeal ruled that financial inability also falls under

\footnotetext{
25 Section 77(2) LRA 1976.

26 Section 92 LRA 1976.

27 Section 93(2) LRA 1976.

28 Section 95 LRA 1976.

29 [1997] 1 MLJ 109.
} 
physical disability. The court ordered the father of the appellant to pay his tuition fees until he graduated with an undergraduate degree. The Court of Appeal made a similar decision in the case of Punithambigai $a / p$ Ponniah $v$ Karunairajah a/l Rasiah ${ }^{30}$ where the father is responsible to pay for the child's tuition fees until higher education. However, the above decision has been set aside by the Federal Court ${ }^{31}$ where the court chose to interpret the term literally and decided that financial inability was not included in the interpretation of physical disability.

The amendment to Section 95 of Act 164 eliminates the obscurity of the responsibility of a father in giving maintenance of the children who are still studying until their graduation. Upon graduation, it is hoped that the child will be able to find a job and support themselves.

The Rules of Court (ROC 2012) also provides adequate procedures which may be applied to enforce the court's order. It includes the Judgment Debtor Summons (JDS), Garnishment, Writ of Seizure and Sales (WSS) and an order of committal.

However, the requirements of the rules that are complex causes difficulties and delays in enforcing and implementing court orders granted under this Act. It includes the requirement of personal service of the summon where the former husband is unknown. The court's procedure also allows an appeal by any party to a higher court after the matter has been decided by the original trial court. The time taken is very long to enable these appeals to be heard and decided which usually hinders the ex-wives from taking their action to the court.

The court jurisdiction over a matter in a case ended once a decision is given. Normally, the court does not interfere with the execution of its judgment and it depends on the will and capabilities of the parties who want to enforce the order.

There are various unintegrated laws. It is difficult to refer or apply these laws. In addition, many of these laws are obsolete and no longer relevant to the current administration of maintenance.

\footnotetext{
30 [2003] 2 MLJ 529.

31 [2004] 2 MLJ 401.
} 


\section{Problems and Arising Issues in Post-Divorce for Non-Muslims}

This study shows that there were many problems faced because of the divorce. This is due to various factors, including the level of education, ignorance of the legal rights and poverty, as well as the absence of a comprehensive point of reference. The arising issues among the nonMuslims include payment of maintenance, division of marital property, and custody of children. This finding is supported by interviews and literature review. During the interviews, all the respondents agreed on the reason for the establishment of one agency as a one-stop centre for single mothers in pre and post-divorce. They state the following:

"... Should (have), a single body, single mother need not to go here and there (looking for assistance) ..."32

"... Need to be materialised (IFDA) so family with problems will get help ..."33

"... Wives should be given the opportunity to voice the problems and pressure caused by the husband..." 34

"... Yes, the ex-husbands has bad character and make his own decision, there is a need for a middle person (or agency) ..." 35

"... Yes, the former husband did not cooperate. Lack of maintenance.. Take advantage of the ignorance and naive of the wife. With this agency, it will be the middle person to talk to the former husband. It's hard to communicate with the former husband ... "36

32 Interview session with interviewee on 10 January 2018 at Bandar Sunway. The interview was conducted at Bandar Sunway and the names of the interviewee cannot be disclosed in the writing due to anonymity and confidentiality.

33 Interview session with interviewee on 10 January 2018.

34 Ibid.

35 Ibid.

36 Ibid. 
From the above statements it is understandable that the creation of an Integrated Family Development Agency (IFDA) is crucial and needed to help single divorced mothers in solving problems arising from their divorce issues.

\section{CONCLUSIONS AND RECOMMENDATIONS}

The research shows that although the provisions of laws existed, but in reality, the enforcement and constraints are obvious, this includes the situation of a former husband who neither has financial resources nor employment. In addition, the former husband himself refuses to comply with the court order and make payment and this is not met with any legal repercussions. Therefore, the enforcement of the court orders requires policies aimed at reforming the law with emphasis on the benefits of the children indirectly involved in the divorce. Moreover, when the responsibility to take care of the children was given to the exwife. ${ }^{37}$ Emphasis must also be given to restore the responsibility of the children involved with divorce to both, the father and mother, despite the fact that they are divorced, rather than putting the sole responsibility on the authorities or the government.

Thus, there is an urgent need for the establishment of an Integrated Family Development Agency (IFDA) which will act as an integrated one-stop centre which adopts a family-friendly method to resolve post-divorce issues. Basically, since it is an issue of enforcing the court order only, this enforcement unit can be applied to the whole society in Malaysia without distinguishing the religion of the applicant. The model and method of implementation of IFDA are proposed to empower family institutions in managing family conflicts, especially in key aspects such as maintenance issues, child custody and matrimonial property. Since this model is holistic, it requires significant changes to the legislation and family-related systems. This

37 Hasbullah, Muslihah; Najibah Mohd Zin; Saodah Wok, (2009) Relationships between Satisfaction of Muslim Women on Financial Supports After Divorce and Ex-Husbands' Compliance to the Supports with Post-Divorce Welfare. Pertanika Journal of Social Sciences \& Humanities. Sep. 2009, Vol. 17 Issue 2, p.153. 
integrated system will emphasize on family-friendly solutions to empower families to assert and fulfil their obligations, rights and responsibilities to all parties involved. The government does not have to be burdened to take over family responsibilities but is obliged to provide facilities and infrastructure that support the establishment of IFDA. The combination of integrated family laws is essential to create uniformity in the implementation. The community will be more acquainted with their rights and responsibilities in terms of family laws by merely referring to a single legislation. 